\title{
Sorrettujen vai kaikkien ihmisten pedagogiikkaa?
}

\author{
Aino Hannula
}

\author{
Kun Paulo Freire kehitti opetusmenetelmäänsä 1960- \\ luvun alussa Brasilian maaseudulla, oli hänen \\ pedagogiikkansa selkeästi sorrettujen pedagogiikkaa. \\ Sorrettujen pedagogiikka perustuu lukutaito-ohjelmiin ja \\ lukutaidon oppimismenetelmään, joita Freire suunnitteli \\ ja toteutti köyhien maatyöläisten parissa. Näissä \\ ohjelmissa yhdistettiin luku- ja kirjoitustaidon oppiminen \\ sekä yhteiskunnallinen tiedostaminen.
}

$F_{h}$ reire sanoi näistä ohjelmista seuraavaa: "Meille lukutaitotyö on pätevää vain silloin, kun ihminen ymmärtää sanan sen oikeassa merkityksessä: maailmaa muuttavana voimana. " Tämä tarkoittaa sitä, että luku- ja kirjoitustaidon avulla ihmiselle avautuu pääsy kirjallisen kulttuurin maailmaan: hän ymmärtää yhteistä, kirjoitettua historiaa ja pystyy osallistumaan päätöksentekoon, joka sääntelee hänen omaa elämäänsä.

$\mathrm{N}$ ämä Brasiliassa toteutetut, valtion tukemat lukutaito-ohjelmat olivat tehokkaita. Miljoonat ihmiset oppivat lukemaan ja lukutaidon myötä he saivat äänioikeuden. Samalla tuli ilmeiseksi tiedostamisen vaarallisuus: aktiiviset, tietoiset kansalaiset voivat olla myös uhka vallitsevalle järjestelmälle. Vuoden 1964 vallankaappauksen yhteydessä Freire ja hänen menetelmänsä tuomittiinkin kommunistisiksi ja kumouksellisiksi. Lukutaito-ohjelmat lopetettiin ja Freire joutui maanpakoon.

Freiren kasvatustyö jatkui maanpaossa Chilessä, josta hän neljän vuoden jälkeen siirtyi lyhyeksi ajaksi Harvardin yliopistoon ja sieltä Kirkkojen
Maailmanneuvostoon Geneveen, jossa hän toimi kasvatustoiminnan asiantuntijana. 1980-luvulla Freire palasi takaisin kotimaahansa. Chilessä ollessaan Freire kirjoitti pääteoksensa Pedagogy of the Oppressed. Nykyään sitä pidetään yhtenä merkittävimpänä kasvatuksen klassikoista. Teos on teoreettinen analyysi siitä, miten kasvatus voi toimia sekä sopeuttavana että vapauttavana. Se on myös julistus kasvatuksen, kasvattajien ja opiskelijoiden tehtävästä toimia inhimillisemmän maailman puolesta.

Koko 1970-luvun ajan Freiren pedagogiikkaa Ppidettiin jonkinlaisena vaihtoehtopedagogiikkana. Sitä sovellettiin kehitysmaiden lukutaito-ohjelmissa, kasvatuksen informaalilla alueella ja myös teollisuusmaiden marginaaliryhmien kasvatuksessa. Mielenkiintoinen sivupolku oli Freiren suosio 1970-luvulla Ruotsissa, jossa se yhdistyi dialogipedagogiikkaan ja sitä sovellettiin päiväkotikasvatuksesta aikuiskoulutukseen. 1980-luvulla Freiren pedagogiikka alkoi saada yleisempää hyväksyntää. Yhtenä syynä tähän oli aikuiskasvatuksen ns. 'kriittinen käänne', emansipatorisen suuntautumisen tuleminen perintei- 
sen työelämäpainotteisen aikuiskoulutuksen rinnalle. Toinen syy oli varmasti muutoksen korostuminen ylipäänsä yhteiskunnassa ja kasvatuksessa. Freiren pedagogiikassa pyrkimyksenä oli sortavan todellisuuden muuttaminen - tämä tarjosi soveltamisperusteita myös muunlaiselle muutoskasvatukselle. Nykyään Freire on kiistatta yksi tärkeimpiä hahmoja aikuiskasvatuksessa ja liittyy erityisesti kasvatuksen emansipatoriseen ja kriittiseen suuntaukseen.

$A_{\text {ei Freiren kasvatusajattelu ollut mitenkään }}^{\text {loittaessani tutkimustani 1990-luvun alussa }}$ muodissa. Tunsin itseni 1970-luvulle jämähtäneeksi, joka hihkuu tasa-arvoa ja solidaarisuutta, Che Guevaraa ja Mao'a. Tutustuessani Freiren teksteihin syvällisemmin yllätyin kasvatusajattelun didaktisesta ajankohtaisuudesta. Keskeisiä ajatuksia olivat kriittinen reflektio, omien kokemusten käyttö, niiden aktivoiminen ja arvioiminen, ongelmakeskeisyys, kommunikaation ja yhteisen kielen opettelun korostus, sosiaalisesti ja yhteisesti rakennettu todellisuus, erilaisten näkemysten liittäminen monimutkaisiin opiskeluteemoihin, laajojen kokonaisuuksien käyttö oppimisessa sekä erityisesti oppijan aktiivisuuden korostaminen. Nämä kaikki ovat keskeisiä asioita tämän hetken oppimisessa, jota sanotaan myös konstruktivismiksi.

Työni valmistuessa vuoden 2000 kynnyksellä yllätyin toisesta ajankohtaisuudesta: Freiren pedagogiikka on tämän hetken Suomessa mitä ajankohtaisin myös sorrettujen pedagogiikkana. Syrjäytyminen, eriarvoistuminen, kapea-alaisuus ja kritiikittömyys, mediavalta, arvojen koveneminen ja yhteisen päätöksenteon karkaaminen tavallisen ihmisen ulottuvilta ovat todellisuutta.

$\mathrm{T}$

utkimukseni aiheena oli Freiren tiedostamiskasvatus ja pyrin erityisesti selvittämään sosiaalisen muutoksen yksilöllisiä edellytyksiä. Tätä varten analysoin, miten Freire kuvaa teksteissään kulttuuripiirissä tapahtuvaa oppimisen prosessia sekä sitä, mitä hän esittää kasvatuksen päämäärästä. (Aiheena tiedostaminen ei ollut kovin omaperäinen. Freire on Knowlesin ohella tutkituimpia aikuiskasvatuksen ajattelijoita. Freiren teoksista Pedagogy of the Oppressed on suosituin ja tiedosta- misen käsite tutkituinta Freireä. Kasvatustodellisuus on kuitenkin erilainen verrattuna 1970lukuun, tiedostamiskasvatuksen suosiovaiheeseen.)

Olenko sitten saanut tutkimuksessani jotain uutta selville? Enpä juuri. Katsaus Freire-tutkimukseen osoittaa, että melkein kaikki saamani tulokset on todettu jo jossain muussa tutkimuksessa.

Mikä sitten on uutta minun tutkimuksessani? Yksi ongelma sekä Freiren pedagogiikan tutkimisessa että soveltamisessa on sen fragmentoituminen. Kasvatuksen didaktista metodia ja kasvatuksen filosofiaa tarkastellaan erillisinä. Usein myös filosofinen tausta - Freiren ajattelun moniaineksisuudesta johtuen - pirstaloituu. Esimerkiksi Freiren ajattelun marxilaisuutta ja kristillisyyttä on ollut vaikea yhdistää. Näin on sivuutettu pedagogiikkaan sisältyvä henkinen elementti tai toisaalta kriittinen yhteiskunnallisuus. Työssäni yritin tarkastella Freiren ajattelua kokonaisuutena, liittää menetelmä ihmiskuvaan ja taustafilosofiaan ja koota ehkä erilaisistakin perinteistä lähtevät käsitteet yhteen.

$\mathrm{P}$ raksis ja dialogi ovat olennaiset tekijät freireäisessä pedagogiikassa ja tutkimuksessani olen selvittänyt näihin sisältyviä oletuksia kasvatuksessa. Näyttääkin siltä, että Freiren itsensä esittämä ja erilaisissa sovelluksissa paljon käytetty generatiivisen teeman metodi on riittämätön tuki freireläistä pedagogiikkaa soveltavalle kasvattajalle. Opettajan on arvioitava myös praksiksen ja dialogin olemusta oppimistapahtumassa. Itse tiedostamisen prosessi osoittautui monimuotoiseksi: 
se on syvällinen muutos, joka ei tapahdu pelkästään todellisuuden tuntemisen ja omien oletusten kriittisen reflektion avulla, vaan oppijan on ratkaistava henkilökohtaisesti myös roolinsa vapaana ihmisenä ja kansalaisena. Taustalla on ihmiskuva, jossa ihminen oletetaan yhteiskunnalliseksi ja myös henkiseksi.

Analyysin kuluessa minulla heräsi kysymys siitä, voiko vapautuksen pedagogiikkaa käyttää myös manipuloivana ja sopeuttavana. Vastaus tähän on että voi. Jos freireläistä kasvatusta sovelletaan pelkkänä metodina irrallaan sen filosofisista perusteista ja ihmiskuvasta, jos abstrakteja käsitteitä ei konkretisoida opiskelijoiden elämänolosuhteisiin, jos kasvatusta ei sovelleta vakavasti niin että ratkaistaisiin oppimiseen liittyviä arvokysymyksiä, voi kasvatus olla myös manipuloivaa. Voisi sanoa niinkin, että pelkkä omien kokemusten käyttö ja niiden reflektio, yhteistoiminnallisuus ja kommunikatiivisuus eivät ole kylliksi vapauttavaksi kasvatukseksi.

Tutkimuksessani pyrin rekonstruoimaan, rakentamaan uudelleen Freiren pedagogiikan keskeisimmän sanoman. Tutkimusta olisi mahdollista jatkaa dekonstruktioon, tarkastella pedagogiikan aukkokohtia, epäjohdonmukaisuuksia ja ristiriitoja. Jo tässä tutkimuksessa paljastui joitakin aukkoja, joista keskeisimpiä on se, että kasvatuksen yhteiskunnallisuudesta ja yhteistoiminnallisuudesta huolimatta Freire ei esitä kytkentää yksilöllisen ja yhteisöllisen tiedostamisen välillä.

\section{Kirjassa Pedagogy of the Oppressed Freire sanoo:}

"Aluksi tämä pedagogiikka on sorrettujen pedagogiikkaa, sorretut paljastavat sorron maailman ja käytännön avulla sitoutuvat sen muuttamiseen. Toisessa vaiheessa, kun sorron todellisuus on jo muutettu, pedagogiikka lakkaa olemasta sorrettujen pedagogiikkaa ja siitä tulee kaikkien ihmisten pedagogiikkaa jatkuvassa vapautumisen prosessissa."

$F_{d}$ reiren pedagogiikka on jo osoittanut mahdollisuuksiaan kaikkien ihmisten pedagogiikkana. Ruotsin dialogipedagogiikka 1970-luvulla on yksi kokeilu tästä. Tulkitsen sen pyrkimykseksi säilyttää ihmisten kyky dialogiin ja vaikut- tamiseen demokraattisessa yhteiskunnassa. Toinen on kriittinen kasvatus ja kriittinen kasvatustiede ylipäänsä, jossa pyritään tarkkailemaan yhteisen toiminnan vääristymiä ja epäoikeudenmukaisuutta.

Onko sorrettujen pedagogiikka sitten jo tarpeetonta? Vapautuksen pedagogiikan sovellukset osoittavat, että sorrettujen pedagogiikka on jatkuvasti tarpeellista. Kasvatusteoriassaan Freire esitti sorron ehkä yksioikoisena: yleismaailmallisena ja sosiaaliluokkien välisenä erona. Ehkä hän uskoi myös, että sorron todellisuus voidaan muuttaa, jos ihmisillä on siihen tahtoa. Postmoderni kriittinen kasvatus ja feministinen kasvatus osoittavat, että länsimainen, postmoderni maailmamme tuottaa uusia ja erilaisia sortoilmiöitä, jotka saattavat olla erillisiä järjestelmiä tai olla yhteydessä keskenään. Näin myös sorrettujen pedagogiikkaa on kehitettävä: jatkuvasti tarvitaan pedagogiikkaa, joka on avoinna erolle ja marginaaliselle kokemukselle, kehittää kriittistä lukutaitoa ja mahdollistaa kielen, jonka avulla voidaan ilmaista omaa subjektiutta ja joka samalla toimii vapauttavana.

Henry Giroux on tulkinnut Freiren pedagogiikkaa kritiikin, mahdollisuuksien ja toivon kieleksi. Kritiikin kielenä siten, että meidän on oltava jatkuvasti avoimia epäoikeudenmukaisuudelle ja kyseenalaistettava vallitsevia käytäntöjä; kasvatus ei ole kuitenkaan vain epäkohtien havaitsemista, vaan sen on etsittävä myös mahdollisuuksia. Toivo on uskoa ihmiseen ja ihmisten kykyyn luoda parempaa maailmaa.

\section{LECTIO PRAECURSORIA}

Esitetty Helsingin yliopiston kasvatustieteellisessä tiedekunnassa 9.6.2000 aikuiskasvatuksen alaan kuuluvan väitöskirjan "Tiedostaminen ja muutos Paulo Freiren ajattelussa. Systemaattinen analyysi Sorrettujen pedagogiikassa." tarkastuksessa. Väitöstilaisuudessa vastaväittäjänä toimi professori Juha Suoranta Lapin yliopistosta. 